\title{
Goldsmithing traditions and innovations in colonial Colombia: an analytical study of crucibles from Santa Cruz de Mompox
}

Marcos Martinón-Torres, Jimena Lobo Guerrero Arenas, Umberto Veronesi and Harriet White Accepted version of a manuscript published in Post-Medieval Archaeology 52/2, 147-169.

\section{Abstract}

The 16th-century Spanish conquest of Colombia brought new technologies that altered and interacted with native metalworking traditions. In the colonial village of Santa Cruz de Mompox, renowned because of its goldsmithing tradition, indigenous groups and Spaniards experienced momentous encounters of individuals, metallurgical technologies and knowledge. However, little is known concerning colonial metallurgy, its continuities and changes with regards to the pre-Columbian period. Here we present the analytical characterization of five crucibles recovered in Mompox, together with discussion of relevant archival evidence. We find evidence for the local manufacture of crucibles as well as for the melting of unrefined gold dust, tumbaga (gold-copper-silver alloys) and silver. These metallurgical practices illustrate some likely illegal activities, continuities with preColumbian traditions in the use of tumbagas, and the Spanish-led introduction of silver in northern Colombia. It is argued that metallurgical remains can be informative of wider social and economic negotiations that engaged indigenous peoples, mestizos and Spaniards, which are critical to understand the configuration of the colonial reality.

\section{INTRODUCTION}

The Momposina Depression is a watershed of around 25,000 square kilometres located in the southern plains of the Colombian Caribbean. It is crossed by the Magdalena River, Colombia's principal waterway, which is joined by the Cauca, César and San Jorge rivers. These rivers periodically flood the region, creating a large inland delta in a vast marshy plain, with an intricate network of streams and swamps (Fig. 1). ${ }^{1}$ During the pre-Columbian period, this region was home to the Zenú culture (200 BC-AD 1600) - a society of farmers and goldsmiths, which also built a sophisticated canal system for agricultural purposes. ${ }^{2}$ 


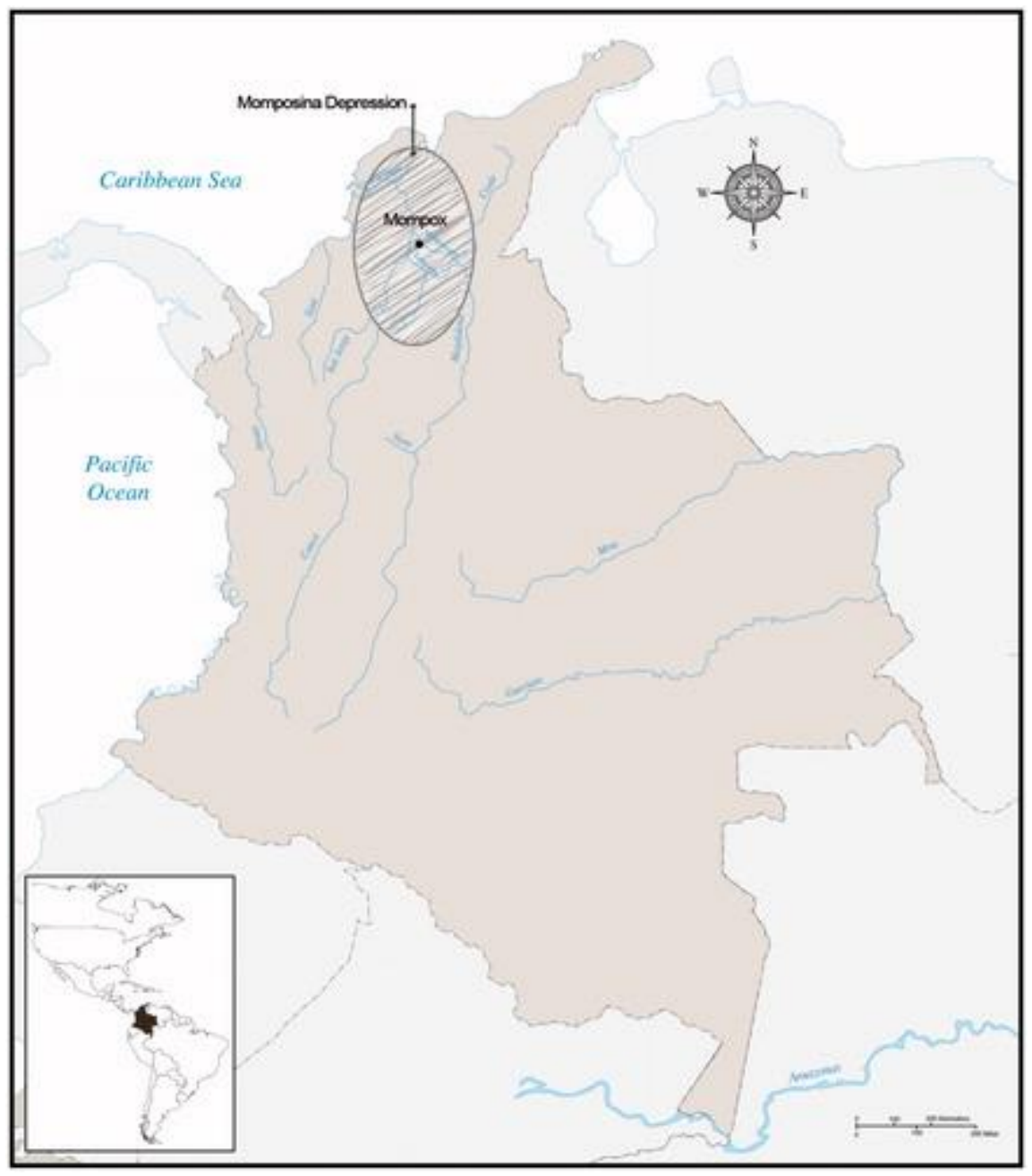

During the 16th century, indigenous groups, including those known as Malibú, came to inhabit the banks of the lower Magdalena River, which is typically considered as one of the main sources of gold in the pre-Columbian period. They wore gold-alloy pendants, circular earrings and so-called false filigree objects. Zenú and Malibú gold objects show formal characteristics linked to earlier Zenú goldwork (150 BC-AD 900), such as the presence of false filigree on earrings. There is also a clear predominance of tumbaga (gold-copper-silver alloys) with low gold contents and the use of casting and gilding techniques which are considered typical of the late period objects of the group of the San Jacinto Mountains, produced from the 17 th century. ${ }^{3}$

Between 1537 and 1540, at the heart of the Momposina Depression, within the boundaries of the Malibú territory ruled by the cacique Mompoj, chief of the Kimbay tribe, ${ }^{4}$ the Spanish conquistador Alonso de Heredia founded the village of Santa Cruz de Mompox (also known as Mompós or Mompox). Mompox was erected in the same fashion as almost every other early Spanish America settlement, with a central plaza and church, and a council house. This last institution gave Mompox a 'village' character. ${ }^{5}$ It was a mixed urban settlement composed of Europeans, indigenous people, African slaves, mestizos, zambos, mulatos and cimarrones (runaway slaves).

Strategically located on the banks of the Magdalena River, during the colonial period Mompox was an obligatory stopping port for all the gold that was extracted from south of the 
territory of New Granada: it all had to be quintado in Mompox. ${ }^{6}$ The quinto real, or royal fifth, was a tax established by royal decree issued in Medina del Campo, Spain, on 8 August 1504. It imposed a $20 \%$ tax on mining production and stated that all gold objects must be marked with the royal fifth, on pain of heavy punishments. ${ }^{7}$ This tax controlled all commercial gold transactions during the 16th and 17th centuries, and led to hundreds of lawsuits, seizures and riots. Thus, much gold circulated within the village both legally and as contraband. Mompox's commercial peak was reached in the 18 th century, ${ }^{8}$ when landowners and businessmen moved south from the Caribbean port of Cartagena de Indias and developed a significant cattle industry. The wars of independence at the beginning of the 19th century, combined with a sudden change in the course of the Magdalena River, left the town partly destroyed and its former glory a distant memory. The change of the course of the river left the city isolated from the rest of the country and prevented its urban development, allowing its colonial characteristics to remain virtually intact. ${ }^{9}$

In part due to this strategic location and the bonanza of the village during the colonial period, both local and foreign goldsmiths settled there to meet the demands of the new colonial society. However, little is known concerning the metallurgical craft in early colonial Mompox, including aspects such as the cultural and technical responses to the encounter with metallurgical traditions brought by Europeans, the permanence of pre-Columbian technical features, the type of metals and alloys used for the fabrication of objects, or the extent to which new tools and knowledge were introduced.

This study seeks to shed initial light on our understanding of some of the elements that characterized early colonial metalworking. As such, it may provide a complement to the also hitherto limited studies of pre-Columbian production remains. Although restricted to the analysis of only five crucibles, the suggestive results show the potential that archaeometallurgical analyzes have amid historical and archaeological studies focusing on post-contact sites. While the production, circulation and use of crucibles across post-medieval Europe and early colonial America have received scholarly attention, ${ }^{10}$ and there is also some work on pre-Columbian crucibles in America, ${ }^{11}$ this area of research is only emerging in Colombia. ${ }^{12}$ Thus it is hoped that the examination of this small sample may open up new research directions.

All five crucibles analyzed were recovered from different excavations in Mompox (Fig. 2). During an archaeological survey carried out in 2009, archaeologist Juan Felipe Pérez Díaz found seven crucibles (three complete forms and the rest fragmentary) in two different excavation units. ${ }^{13}$ The better preserved crucibles were recovered at the Plaza de San Francisco, at a depth of $1.9-2.1 \mathrm{~m}$ in a $1 \times 1 \mathrm{~m}$ pit identified as TFTP-1: these are a triangular crucible (sample \#2) and a beaker-shaped crucible (\#3). In addition, we selected a smaller crucible fragment found at the Plaza de Santa Barbara in an excavation unit of $1 \times 1 \mathrm{~m}$ identified as STS-6 (\#1). This was found at between $2 \mathrm{~m}$ and $2.2 \mathrm{~m}$ depth and was associated with colonial ceramics of the Crespo tradition (16th to 18 th centuries). ${ }^{14}$ 


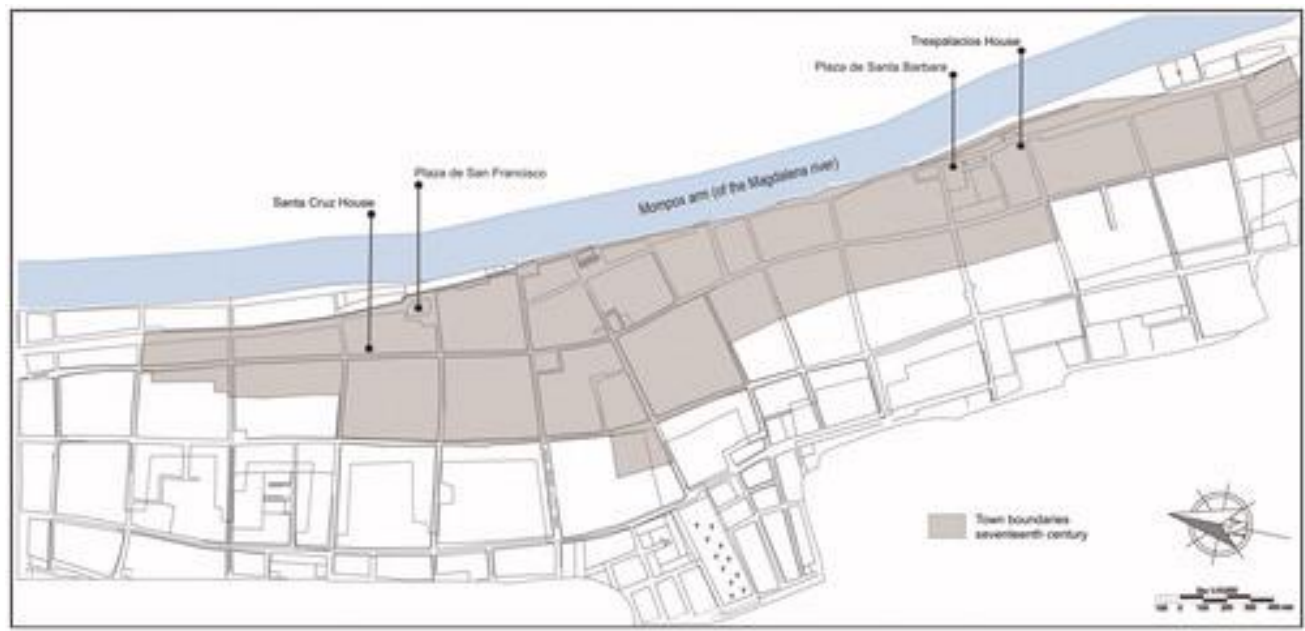

On the other hand, in 2014, additional crucible fragments were recovered at excavations carried out inside two houses where goldsmithing is known to have been carried out over at least three or four generations. ${ }^{15}$ The archaeological work took place in both houses in the form of an excavation unit of $1 \times 1 \mathrm{~m}$ located in the central patio. At Trespalacios House, small fragments of crucibles were found alongside colonial ceramics from the 17th and 18th centuries, at between $80 \mathrm{~cm}$ and $1.2 \mathrm{~m}$ depth inside a colonial cistern that at some point around the 17th century became a trash pit. The archaeological context of this excavation unit also included some other metalwork-related objects such as small pieces of slag, a small stone round bar with a spiked end that may have been an embossing tool, and a piece of corroded iron $(11 \times 3 \mathrm{~cm})$ that seemed to correspond to a draw plate used for making metal threads (\#5). Meanwhile, at Santa Cruz House, two small fragments were found at $60 \mathrm{~cm}$ depth alongside local ceramics and imported majolica within a similar chronological frame (\#4).

\section{ANALYTICAL METHOD}

Crucibles were exported to the UK for analytical characterization with a permit from the Colombian Institute of Anthropology and History. The analyzes were carried out at the Wolfson Archaeological Science Laboratories of the UCL Institute of Archaeology in London.

An initial qualitative assessment of all crucible fragments using non-invasive portable $X$-ray fluorescence (pXRF) allowed for the identification of traces of copper, silver and gold in many of the fragments, together with occasional traces of lead and zinc. The fragments were also examined using a digital microscope, which allowed an initial assessment of the crucible fabrics and residues within their inner surfaces, most notably globules of noble metals embedded in some of them. However, surface analysis could not allow any inferences beyond confirming the practice of noble metal metallurgy. Hence, five crucible fragments were selected covering different archaeological contexts, vessel typologies and residues detected by pXRF and digital microscopy. Small cross-sections of these were cut and embedded in epoxy resin prior to grinding and polishing down to a grain size of $1 \mu \mathrm{m}$ following standard procedures.

These sections were subsequently examined by reflected light optical microscopy before carbon-coating for analysis by scanning electron microscopy with energy dispersive spectrometry (SEM-EDS), which allows high-magnification imaging as well as 
compositional analyzes of selected areas of the mounted specimens The instrument employed was a Philips XL30 SEM with an Oxford Instruments EDS. Operating conditions were as follows: accelerating voltage of $20 \mathrm{kV}$, working distance of $10 \mathrm{~mm}$, acquisition time of $100 \mathrm{~s}$, and process time of 4.8. A cobalt standard was analyzed at regular intervals. Data quality was assessed via the analysis of basalt standard BHVO-2 (broadly comparable to the slag layers and minerals analyzed) and three certified gold alloys (MAC 1, 2 and 3). Results of these tests are presented in Tables A1 and A2.

An approximation to the bulk chemical composition of ceramics was obtained by analyzing several relatively large areas of the section, $c .2 .5 \times 2 \mathrm{~mm}$ each, including any mineral inclusions present in them. These results are reported as 'bulk' compositions. In addition, several smaller areas were analyzed in each section, $c .120 \times 100 \mu \mathrm{m}$, focusing on the ceramic matrix and avoiding larger inclusions. These are reported as 'matrix' analyzes. Vitrified layers on the inner surface of the vessels were analyzed in the same fashion as crucible matrices. In addition, areas rather than spots were analyzed preferentially when probing minerals and metal globules. When individual measurements fell below detection limits of the EDS $(\sim 0.1 \%)$, these were computed as zeros for the calculation of averages. Results are presented as percentages by weight $(\%)$ normalized to $100 \%$, outputting data as elements for metal phases, and adding oxygen by stoichiometry for ceramics, minerals and slag. Empty cells in results tables mean all analyzes fell below detection limits for that sample and element.

\section{CRUCIBLE TYPOLOGIES AND FABRICS}

The majority of the crucible fragments recovered are small sherds, which do not allow for a reliable estimate of the crucibles' original shape or size. However, their curvature and thickness (3-4mm in all cases) suggest that the original vessels would have been relatively small, with volumes of perhaps $20 \mathrm{ml}$ or less, and thus indicative of small-scale activities. Only two of the vessels are more complete, and they are consistent with this inference: Crucible \#2 is a so-called triangular crucible, a very common type in post-medieval Europe, characterized by its round, flat bottom and its triangular mouth (Fig. 4a). This shape was achieved simply by folding the rim of the vessel inwards before firing it in the potter's kiln. It became very popular as it provided three convenient pouring spouts. Triangular crucibles have been recovered across the world used by metallurgists, assayers, coin minters, alchemists and others. ${ }^{16}$ The triangular crucible from Mompox, recovered at Plaza de San Francisco, is approximately $6 \mathrm{~cm}$ in height and $3 \mathrm{~cm}$ in rim side, a medium-to-small size. The other well-preserved crucible (\#3), found at the same location, is of comparable size. It has a flat, rounded base, too, and a preserved height of $6.7 \mathrm{~cm}$; the rim appears to be rounded, with a diameter around $3 \mathrm{~cm}$, but it is not possible to rule out completely the possibility that it might have had a triangular rim, as the sides of these were sometimes curved (Fig. 5a). 
FIG. 3 Crucible sherd \#1. a) Overview of the inner surface of the sherd; b) Detail of the inner surface under the digital microscope, showing numerous gold-rich globules embedded in the vitrified layer; c) Cross-section of the sherd under the SEM, showing a ceramic fabric rich in small quartz grains and argillaceous inclusions, and a thin vitrification layer on the inner surface (top) with a partly corroded metal prill embedded; d) Detail of the ceramic fabric, showing a highly vitrified argillaceous lump.
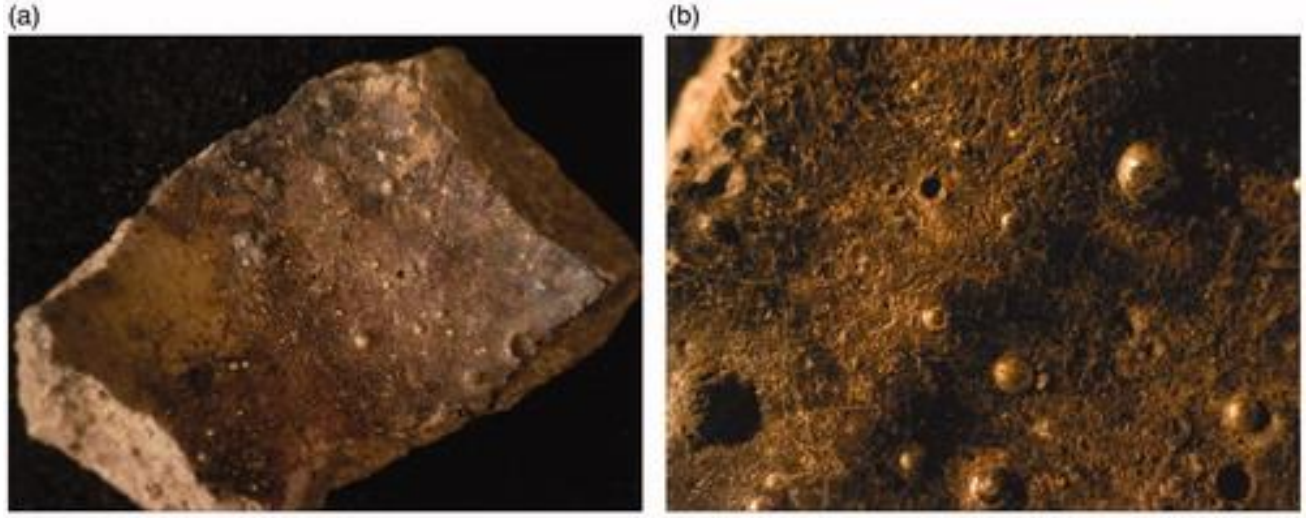

(c)

(d)
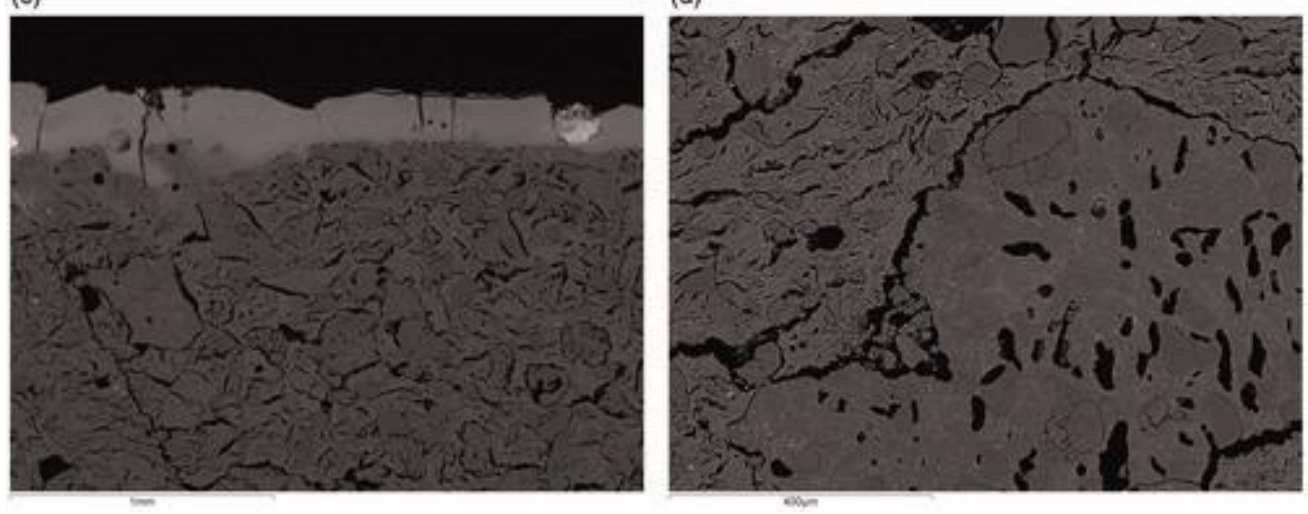

\section{EUROPEAN CRUCIBLES?}

Turning to the crucible fabrics, four of the five samples analyzed in cross-section (\#1, 2, 3 and 5) fall in the same broad category: they are made of white-firing, non-calcareous clays with relatively high alumina levels and very low levels of iron oxide $(<1.5 \% \mathrm{FeO})$ and alkali and alkali earth oxides ( $<4 \%$ total sum of $\mathrm{Na}_{2} \mathrm{O}, \mathrm{MgO}, \mathrm{K}_{2} \mathrm{O}$ and $\mathrm{CaO}$ ). Analyzes of the clay matrix show variable levels of alumina, ranging from $24.6 \%$ (\#1) to $31.1 \%$ (\#3), but overall their compositions are quite similar and potentially consistent with a single clay source (Table 1). In all cases, the main inclusions documented within the fabrics are quartz $\left(\mathrm{SiO}_{2}\right)$ grains and argillaceous lumps. In crucibles \#2 and \#3, quartz inclusions are relatively scarce but reach larger sizes ( $\leq 500 \mu \mathrm{m}$ in diameter) (Figs $4 \mathrm{~b}, 5 \mathrm{~b}$ ), whereas in crucibles \#1 and \#5 both quartz grains and especially argillaceous lumps are much more abundant, but also typically better sorted and smaller $(\leq 300 \mu \mathrm{m})$. These argillaceous pellets are compositionally similar to the main ceramic matrix, sometimes higher in alumina, but they appear more vitrified, as noticeable in the more rounded voids they contain, as well as in their internal recrystallization, which denotes exposure to temperatures in excess of $1200^{\circ} \mathrm{C}$ (Figs $3 \mathrm{c}, 3 \mathrm{~d}$, $8 \mathrm{~b}, 8 \mathrm{c})$. This is particularly noticeable in crucible \#5. As such, it is possible that these lumps constitute grog, that is, fragments from another crucible or other ceramic that would have been pre-fired or used under very high temperatures, prior to crushing and mixing with fresh clay to manufacture the vessel studied here. 
FIG. 4 Triangular crucible \#2. a) Overview of the crucible as recovered; b) Ceramic cross-section under the SEM, showing abundant quartz (dark grey) and elongated, angular porosity (black); c) Detail of the cross-section of the inner layer, showing a variety of metal and minerals in a glassy matrix (Au: metal prill; M: titaniferous magnetite; C: cassiterite; P: rare earth phosphate; Q: quartz).

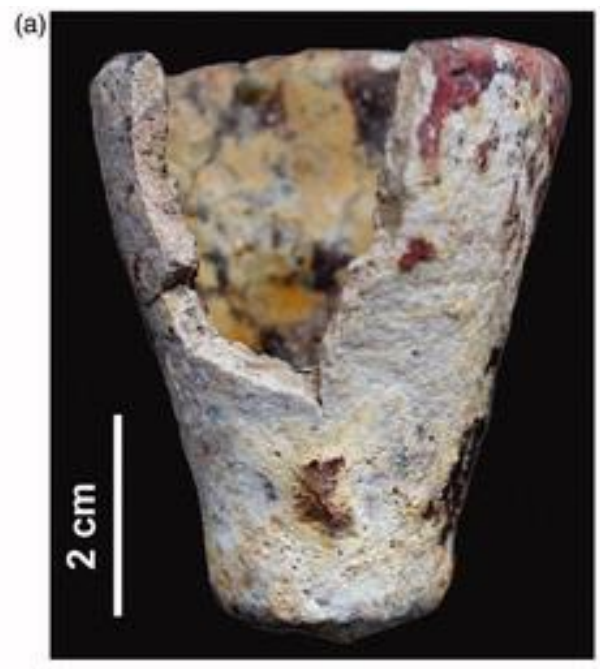

(b)

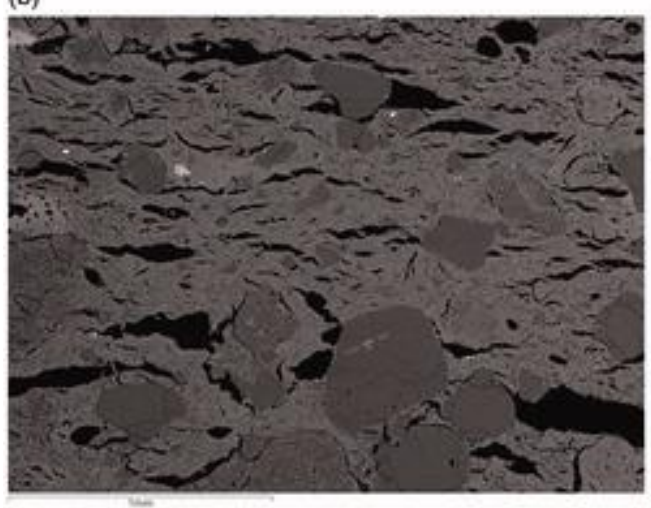

(c)

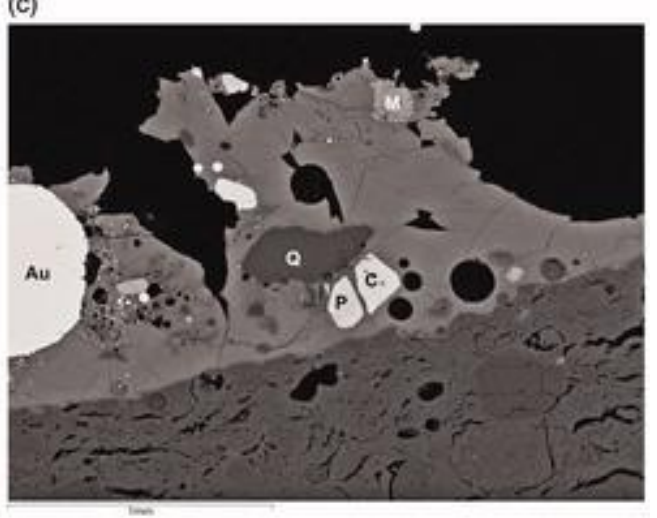

Table 1 Average chemical composition of the ceramic crucibles analyzed by SEM-EDS.

$\mathrm{Na}_{2} \mathrm{O} \mathrm{MgO} \mathrm{Al}_{2} \mathrm{O}_{3} \mathrm{SiO}_{2} \mathrm{P}_{2} \mathrm{O}_{5} \mathrm{Cl} \mathrm{K}_{2} \mathrm{O} \mathrm{CaO}_{\mathrm{TiO}_{2}} \mathrm{FeO}$

\begin{tabular}{|c|c|c|c|c|c|c|}
\hline \#1 matrix 0.6 & 0.1 & 24.6 & 70.1 & 0.11 .5 & 0.5 & 1.2 \\
\hline \#2 matrix 0.3 & 0.4 & 27.8 & 66.40 .2 & 1.6 & 0.3 & 1.5 \\
\hline \#3 matrix 0.3 & 0.4 & 31.1 & 62.90 .1 & 1.9 & 0.2 & 1.5 \\
\hline \#5 matrix 0.2 & 0.2 & 30.8 & 64.20 .2 & 0.11 .1 & 0.4 & 1.2 \\
\hline \#4 matrix 1.6 & 0.1 & 29.3 & 63.4 & 0.51 .0 & 0.4 & 1.0 \\
\hline \#1 bulk 0.6 & 0.2 & 21.7 & 72.9 & 0.11 .3 & 0.6 & 1.3 \\
\hline \#2 bulk & 0.3 & 22.3 & $72.8 \quad 0.1$ & 1.5 & 0.2 & 1.3 \\
\hline \#3 bulk & 0.3 & 23.4 & 71.60 .1 & 1.4 & 0.2 & 1.3 \\
\hline \#5 bulk & 0.2 & 28.1 & 67.10 .2 & 1.2 & 0.3 & 1.2 \\
\hline \#4 bulk & 0.4 & 26.6 & 64.4 & 0.31 .0 & 1.4 & 0.9 \\
\hline
\end{tabular}

The combination of alumina-rich, flux-poor clays with abundant inclusions would have rendered these crucibles sufficiently refractory and thermal shock resistant to perform their function. ${ }^{17}$ In all cases, these ceramics clearly withstood exposure to high temperatures without collapsing. While the matrices show round voids and signs of vitrification, and quartz 
grains are sometimes thermally shattered (samples \#2 and \#3), the fabrics retain angular macroporosity oriented parallel to the vessels' surfaces, and are clearly far from failure.

The quartz-rich fabrics of these four crucibles are notably different from that of crucible \#4, identified below as a local product. This raises the possibility that they could have been made outside the Mompox basin or indeed imported from Europe. The triangular shape of crucible \#2 and generally the quartz-rich paste are consistent with those of crucibles manufactured in Hesse, Germany, which became the main crucible production region in the post-medieval world. ${ }^{18}$ Besides numerous locations in Europe, Hessian crucibles have been recovered in colonial Jamestown (Virginia, US), the first British settlement in America. ${ }^{16}$ A nest of triangular crucibles found at the mouth of the Guadalquivir River in Spain, in a necessary step of the route between Seville and the Indies, indicates that Hessian crucibles may have been in the cargo of Spanish ships that sailed to South America. ${ }^{19}$ Having said this, it should also be noted that the earliest crucibles taken by Spaniards to America, namely those found at the town of La Isabela in the Dominican Republic, are graphitic and most probably from Bavaria rather than Hesse. ${ }^{20}$ Furthermore, Hessian crucibles analyzed so far have been shown to be made of kaolinitic clays with alumina levels always exceeding $35 \%$, hence more alumina-rich than those from Mompox. ${ }^{18}$ Thus, although a European origin is plausible, this extent cannot be confirmed without more detailed petrographic and trace element analyzes, especially given their mineralogical simplicity and our limited knowledge of the clay resources available around Mompox.

\section{A COLOMBIAN CRUCIBLE}

Crucible \#4 stands out in its slightly different composition, most notably in the higher soda and iron oxide levels (Table 1), but also and especially in the nature of the mineral inclusions, which are poorly sorted and very abundant within the fabric. Given the singularity of this sherd, 80 of these mineral inclusions were analyzed by SEM-EDS using small area analyzes, to aid their identification and inform about the provenance of the vessel (Table A3). The ceramic is dominated by feldspar grains, but fragments of volcanic glass are relatively frequent too, in addition to less abundant quartz, amphibole, titaniferous magnetite and metamorphosed aluminium silicates (andalusite/kyanite/sillimanite) (Fig. 6a, 6b). Following the approach taken by Freestone, ${ }^{21}$ the proportions of albite, anorthite and orthoclase were calculated for 38 feldspar grains based on their chemical composition, and the results plotted in a ternary diagram (Fig. 7). These compositions fall into two of the provenance regions demarcated by Trevena and $\mathrm{Nash}^{22}$ in their study of feldspar provenance: volcanic and volcanic + plutonic. The relatively high barium oxide levels detected in some of the feldspars $(\leq 1.85 \% \mathrm{BaO})$ are characteristic of evolved lavas, confirming their volcanic origin. Ten additional volcanic rock fragments were analyzed, most of them glassy but including some of porphyritic texture. All of them are of subalkaline composition, falling in the rhyolite region when plotted on a total alkali silica (TAS) diagram. ${ }^{23}$ The occurrence of rhyolite is consistent with Andean calc-alkaline volcanism, and specifically with the Northern Volcanic Zone (i.e. Colombia and Ecuador), which is particularly rhyolitic in character ${ }^{24}$ All the mineralogical and geochemical data are therefore consistent with the geology of the region around Mompox, and thus leave little doubt that this crucible was made locally.

\section{METALLURGICAL PROCESSES}

The analysis of the vitrified layers on the inner surface of the crucible sherds and the metal prills contained within allows inferences about the metallurgical processes that may have 
taken place in these vessels. When performing this kind of analysis, it is important to bear in mind that the composition of the metal prills within a crucible slag layer may not reflect exactly the bulk composition of the metal melted within, due to local concentration effects and the potentially heterogeneous redox conditions within different parts of the crucible leading to selective oxidation. ${ }^{25}$ The metallurgical signature of a vessel may be further blurred by repeat uses of the same crucible for different processes. Notwithstanding these challenges, the combination of microscopic and chemical microanalyzes of crucible slag by SEM-EDS remains arguably the best approach to the underlying technology. ${ }^{26}$

\section{MELTING OF ALLUVIAL GOLD}

The surfaces of crucible \#2 are vitrified, particularly on the inner side, which is covered by a yellow-orange glassy film. Several droplets of metal can be seen embedded in this layer when the whole crucible is examined under a microscope. The section mounted for analysis came from the top part of the crucible, near the rim, thus the area where any impurities in the charge would have floated on top of molten metal. The slaggy layer adhering to the surface varies in thickness from $300 \mu \mathrm{m}$ to over $1 \mathrm{~mm}$. Compositionally, this glass is mostly enriched in potash and soda compared to the ceramic itself, in addition to more moderate enrichment in oxides of iron, copper, lead, calcium, titanium, arsenic, sulphur, cerium and platinum (Table 2). Of particular interest is the cluster of metallic prills and residual minerals identified. Here, there is a concentration of metallic globules of different sizes up to $1 \mathrm{~mm}$ in diameter, all of them constituting argentiferous gold with small traces of copper and lead (Table 3). Intermixed with them within the alkali-rich glass is a range of minerals. SEM-EDS analyzes allowed the identification of these as hafnium-bearing zircon $\left(\mathrm{ZrSiO}_{4}\right)$, cassiterite $\left(\mathrm{SnO}_{2}\right)$, titaniferous magnetite $\left(\mathrm{Fe}[\mathrm{Fe}, \mathrm{Ti}]_{2} \mathrm{O}_{4}\right)$ and a rare earth phosphate, probably monazite ([Ce,La, Th,Nd,Y] $\mathrm{PO}_{4}$ ) (Table 4; Fig. 4c). All of these are nodular and show diffuse contours, indicating that they entered the charge as natural minerals and were partly dissolving in the slag when the operation finished - as also reflected in the slag enrichment in relevant elements. This is particularly noticeable in the case of cassiterite, which is known to grow in the form of euhedral crystals when formed by the oxidation of metallic $\operatorname{tin}^{27}$ — hence totally different from the morphology recorded here. In other words, we can confidently identify these minerals as part of the charge that entered the crucible with the metal.

Table 2. Average chemical composition of the inner vitrified layer/slag matrix of the crucibles analyzed by SEMEDS, avoiding residual minerals or large metal globules.

\begin{tabular}{|c|c|c|c|c|c|c|c|c|c|c|c|c|c|c|c|}
\hline crucible & $\mathrm{Na} 2 \mathrm{O}$ & $\mathrm{MgO}$ & $\mathrm{Al} 2 \mathrm{O} 3$ & $\mathrm{SiO} 2$ & P2O5 & $\mathrm{SO} 3$ & $\mathrm{Cl}$ & $\mathrm{K} 2 \mathrm{O}$ & $\mathrm{CaO}$ & $\mathrm{TiO} 2$ & $\mathrm{FeO}$ & Cu2O & $\mathrm{ZnO}$ & As203 & $\mathrm{Ag} 2 \mathrm{O}$ \\
\hline$\# 1$ & 9.7 & 0.7 & 12.9 & 41.8 & 1.3 & 0.1 & 0.3 & 8.1 & 4.4 & 1.2 & 9.6 & 6.6 & 1.9 & & 0.4 \\
\hline$\# 2$ & 5.7 & 0.3 & 14.9 & 39.6 & 1.6 & 0.1 & & 20.5 & 1.6 & 2.2 & 7.8 & 2.0 & & 0.3 & \\
\hline$\# 3$ & 0.8 & 0.7 & 19.1 & 60.9 & 1.5 & & & 4.6 & 6.3 & 1.0 & 3.9 & 0.4 & & & \\
\hline$\# 4$ & 18.3 & 0.5 & 16.8 & 48.1 & 0.4 & & 0.2 & 0.5 & 1.8 & 1.3 & 6.5 & 1.5 & 1.3 & & 2.7 \\
\hline$\# 5$ & 1.2 & 0.4 & 18.8 & 60.0 & 1.9 & & & 3.3 & 7.0 & 1.0 & 5.9 & 0.5 & & & \\
\hline
\end{tabular}


Table 3 Chemical composition of metal prills within crucible slag layers obtained by SEM-EDS small area analyzes. (*: minor amounts of $\mathrm{Mg}, \mathrm{Al}$, Si and Ca were also detected in the analysis of this prill, which was clearly corroded).

\begin{tabular}{lccccccc} 
crucible & $\mathrm{O}$ & $\mathrm{S}$ & $\mathrm{Cl}$ & $\mathrm{Fe}$ & $\mathrm{Cu}$ & $\mathrm{Ag}$ & $\mathrm{Au}$ \\
\hline$\# 1$ & 2.5 & & & 0.4 & 3.5 & 93.6 & \\
$\# 1$ & 0.9 & & & 22.4 & 10.3 & 66.4 & \\
$\# 1$ & 0.7 & 0.4 & 59.4 & 11.1 & 28.4 & & \\
$\# 1$ & 5.5 & 0.3 & 0.4 & 0.4 & 2.8 & 90.6 & \\
$\# 1 *$ & 34.4 & & 3.4 & 0.4 & 24.2 & 32.4 & 2.0 \\
\hline$\# 2$ & 1.1 & & & & 0.7 & 11.0 & 87.3 \\
$\# 2$ & 1.1 & & & & 1.7 & 34.9 & 62.3 \\
$\# 2$ & 0.8 & & & & 14.0 & 27.5 & 57.7 \\
\hline$\# 3$ & & & 0.2 & & 8.6 & 41.6 & 49.6 \\
$\# 3$ & & & & & 7.9 & 45.0 & 47.1 \\
$\# 3$ & & & 0.2 & & 8.3 & 43.3 & 48.4 \\
$\# 3$ & & & & 0.4 & 5.9 & 93.7 & \\
\hline$\# 4$ & 1.7 & & & 0.5 & 19.2 & 78.6 & \\
$\# 4$ & 1.3 & & & 0.3 & 7.4 & 91.0 & \\
$\# 4$ & 1.2 & & & & 14.7 & 84.2 & \\
$\# 4$ & & & & & 9.4 & 90.6 & \\
\hline$\# 5$ & 1.4 & & & & 48.7 & 7.9 & 42.0 \\
\hline
\end{tabular}

Table 4. Chemical composition by SEM-EDS of minerals identified within the vitrified layer of crucible \#2.

\begin{tabular}{|c|c|c|c|c|c|c|c|c|c|c|c|c|c|}
\hline crucible \#2 & $\mathrm{Na} 2 \mathrm{O}$ & $\mathrm{MgO}$ & $\mathrm{Al} 2 \mathrm{O} 3$ & $\mathrm{SiO} 2$ & P2O5 & $\mathrm{CaO}$ & $\mathrm{TiO} 2$ & V2O5 & $\mathrm{MnO}$ & $\mathrm{FeO}$ & $\mathrm{Rb} 20$ & $\mathrm{ZrO} 2$ & $\mathrm{Nb} 2 \mathrm{O} 5$ \\
\hline zircon & & & & 32.2 & & & & & & & & 66.3 & \\
\hline zircon & & & & 32.7 & & & & & & & & 66.1 & \\
\hline cassiterite & 0.6 & & 1.2 & 3.1 & & & & & & 0.9 & & & 1.0 \\
\hline cassiterite & & & & & & & & & & 0.5 & 0.6 & & 1.1 \\
\hline Ti-magnetite & & 0.9 & 0.6 & & & & 29.6 & 0.7 & 0.2 & 68.1 & & & \\
\hline monazite? & & & & 1.0 & 29.6 & 0.8 & & & & & & & \\
\hline
\end{tabular}

The silver content in the gold is quite high, exceeding 30\% in the larger prills. However, Colombian alluvial gold is known to contain relatively high amounts of silver, with extreme values reaching $35 \%,{ }^{28}$ hence these silver levels may be regarded as plausibly natural. Copper levels around $1 \%$, and especially an extreme value of $14 \%$, are relatively high when compared to those of alluvial gold from Colombia analyzed previously, and perhaps the enrichment reflects contamination from other minerals or from previous uses of the crucible involving this metal. The same may apply to the occasional traces of lead. As for the minerals identified, these are all heavy minerals often associated with granite. Altogether, the evidence strongly indicates that the crucible was once used to melt natural gold dust or nuggets obtained from an alluvial deposit, as opposed to metal scrap or ingots. When collecting these nuggets, inevitably some heavy minerals in addition to the gold will enter the charge and will be separated from the metal by density upon melting. In this case, the nature of these minerals allows us to connect the gold to the weathering of a granitic substrate, which suggests a connection with the Mompox basin itself, which is dominated by granite. ${ }^{29}$ As a matter of fact, the Magdalena River, which crosses the Mompox basin, together with its main 
tributaries, is thought to have been one of the main sources of gold in the pre-Columbian period. ${ }^{30}$ The north-west termination of the Serranía de San Lucas, which borders with Mompox, is one of the richest gold mineralizations in Colombia, and one that would naturally feed alluvial deposits and placers around the Momposina Depression. ${ }^{31}$ The slag enrichment in soda and potash may be due to the use of a flux or perhaps just reflect the former presence of alkali-rich minerals or fuel in the charge. As for the platinum, it is important to note that it appears in the glass rather than in the metal phase. The latter is more common in alluvial gold, which can contain inclusions of platinum group metals when these are present in the parent rock. ${ }^{32}$ In this case, it is possible that residual arsenides or sulphides of platinum were present in the charge, too, which would also explain the traces of arsenic and sulphur in the vitrified layer.

\section{MELTING OF GOLD ALLOYS}

Traces of gold were detected in two further crucibles, but always in copper-rich, hence artificial, alloys. In crucible $\# 5$, a single $500 \mu \mathrm{m}$ prill was found to contain $8 \%$ silver and $49 \%$ copper alloyed with gold (Table 3; Fig. 8a, 8c). The vitrified layer where this is embedded appears corroded, although enrichment in lime, iron, potash, phosphate and soda compared to the ceramic is noticeable (Table 2). An alloy of this composition could have been obtained by melting equal parts of alluvial gold (with $c .16 \% \mathrm{Ag}$ ) with metallic copper. This is the composition of many pre-Columbian tumbagas and thus makes it plausible (but by no means proved) that indigenous loot might have been melted in this vessel. In crucible \#3, the proportions among the alloy constituents are reversed, with $8 \%$ copper and around $43 \%$ silver in the larger prills (Table 3). Unlike the previous case, the high $\mathrm{Ag} / \mathrm{Au}$ ratio indicates that creating this alloy would have required the addition of metallic silver. This is perhaps corroborated by the presence of a very small globule of almost pure silver with $6 \%$ copper. The vitrified layer is weathered, too, and its composition is comparable to that of crucible \#5 but with a trace of tin oxide (Table 2; Fig. 5c). 
FIG. 5 Crucible \#3. a) Overview of the crucible as recovered; b) Fabric cross-section under the SEM, showing quartz (dark grey), angular porosity (black) and argillaceous lumps; c) Detail of the cross-section near the surface (top) showing the penetration of the metal-rich (bright) layer through cracks in the fabric; note the postdepositional weathering of the vitrified inner surface.

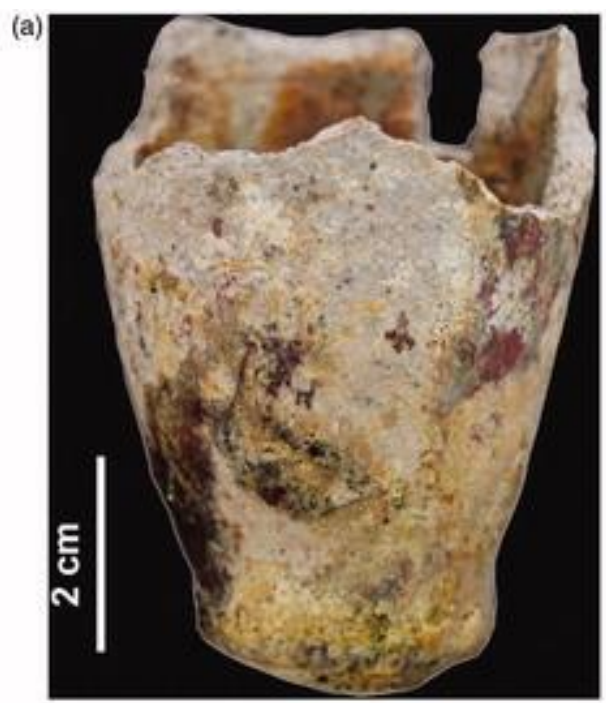

(b)

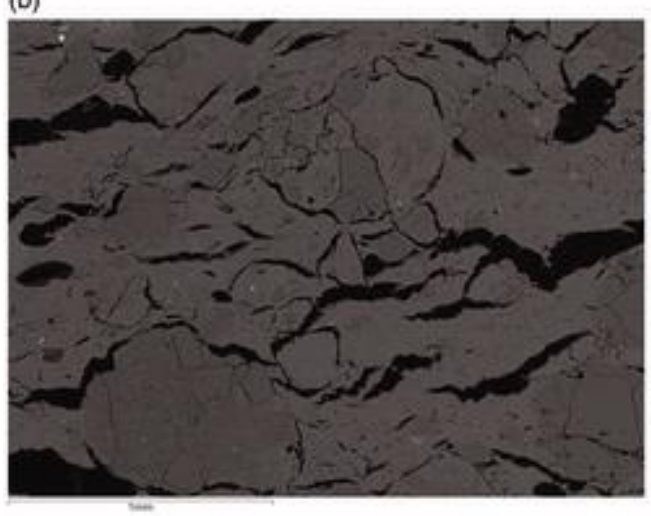

(c)

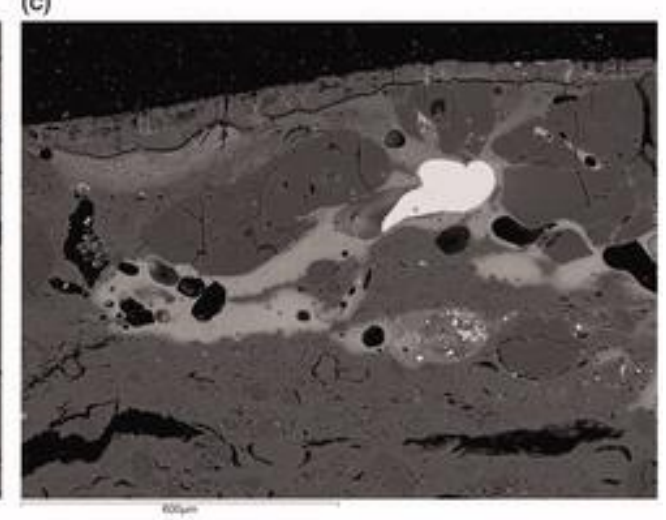

\section{MELTING OF SILVER ALLOYS}

The remaining two crucibles present evidence of the melting of silver alloys. Crucible \#4 contains numerous very small $(<100 \mu \mathrm{m})$ prills of metal embedded in a very soda-rich layer, which is also marginally enriched in iron, copper, zinc and silver (Table 2; Fig. 6c, 6d). SEMEDS analyzes of the metal globules were compromised by their small size, but they consistently showed them to be silver alloyed with copper (8-19\%), containing occasional traces of iron $(<0.5 \%)$ (Table 3$)$. This is the only crucible analyzed where no gold was detected at all. Alloys of silver and copper in these proportions do not tend to occur naturally, since native silver is rare and typically rather pure. ${ }^{33}$ If the silver was obtained by the smelting of argentiferous ores followed by cupellation, then any copper present would have been removed. Hence, we are compelled to infer that this crucible was used to melt an artificial alloy of silver and copper, perhaps with a small amount of zinc as an impurity. The addition of copper to silver is common throughout the history of metallurgy, from jewellery to coin making, since pure silver is too soft and needs to be alloyed to be hardened. Hence, this crucible might represent the remains of alloying of copper and silver or, perhaps more likely, simply the re-melting of some silver-alloy coins or scrap. As in other crucibles, it is 
not possible to establish whether the alkali enrichment in the vitrified layer denotes deliberate fluxing or, perhaps more likely, contamination from minerals or fuel ash.

FIG. 6 Crucible \#4. a) and b) Two views of the cross-section of the crucible fabric under the SEM, showing the abundance of mineral inclusions that are markedly different from those in the other crucibles analyzed ( $F$ : feldspar; R: rhyolite; A: amphibole; Q: quartz; AS: aluminium silicate); c) and d) Views of the cross-section near the inner surface of the vessel (top), showing a vitrified layer with round voids (black) and numerous metal prills (white) of widely different diameters.

(a)

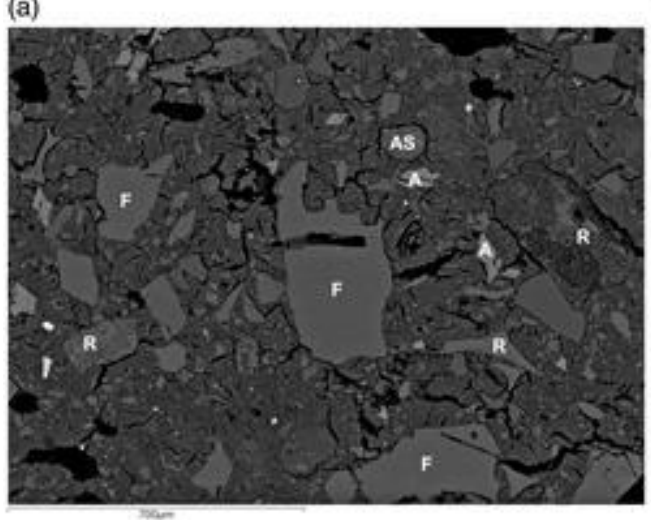

(c)

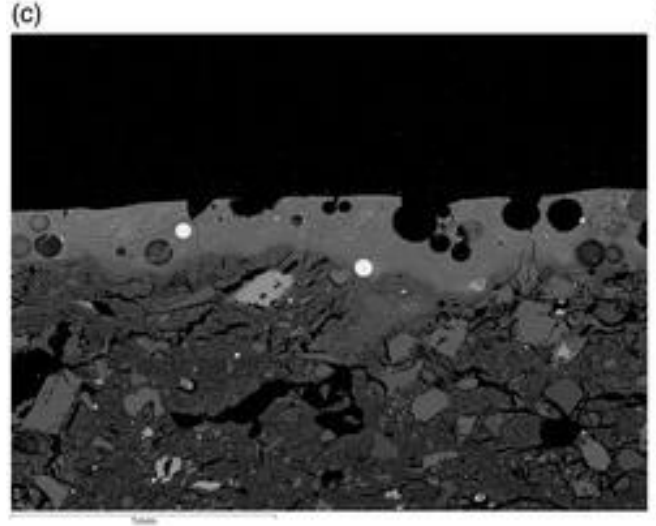

(b)

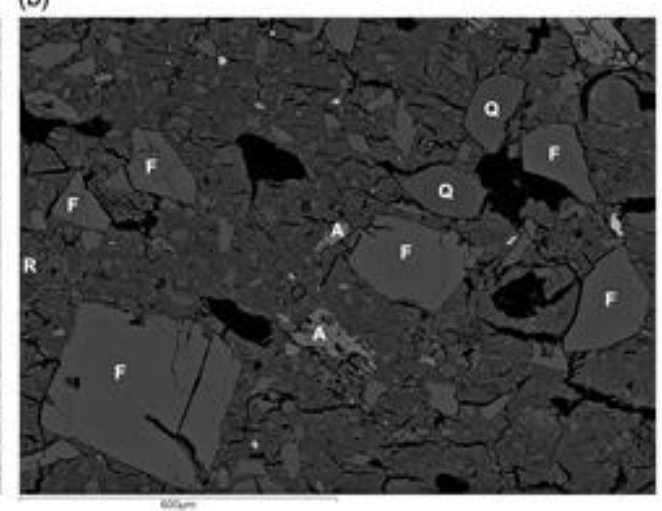

(d)

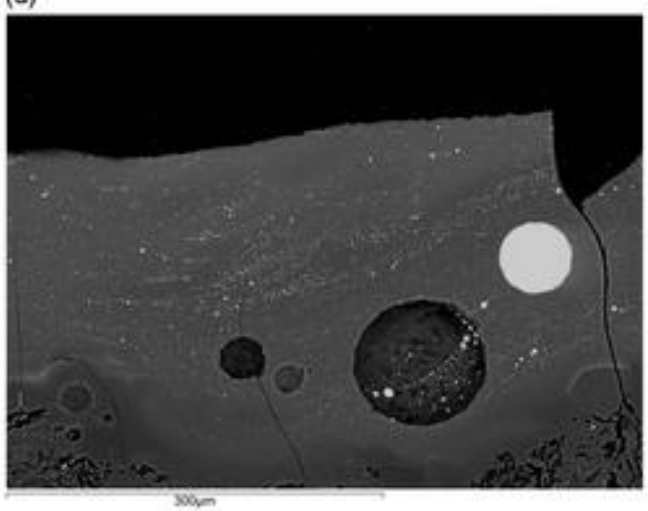


FIG. 7 Compositions of feldspars from crucible \#4 plotted in terms of their weight per cent anorthite (An), albite (Ab) and orthoclase (Or). The diagram showing boundaries between feldspars from different rock types is redrawn after Trevena and Nash (1981 Trevena, A.S. \& Nash, W.P. 1981, 'An electron microprobe study of detrital feldspar', Journal of Sedimentary Petrology 51, 137-49. [Google Scholar]) (v: volcanic; p: plutonic; m: metamorphic; $v+g$ : volcanic or granophyre; $v+p$ : volcanic or plutonic; $p+m$ : plutonic or metamorphic: $v+p+m$ : volcanic, plutonic or metamorphic; $p+m+a$ : plutonic, metamorphic or authigenic).

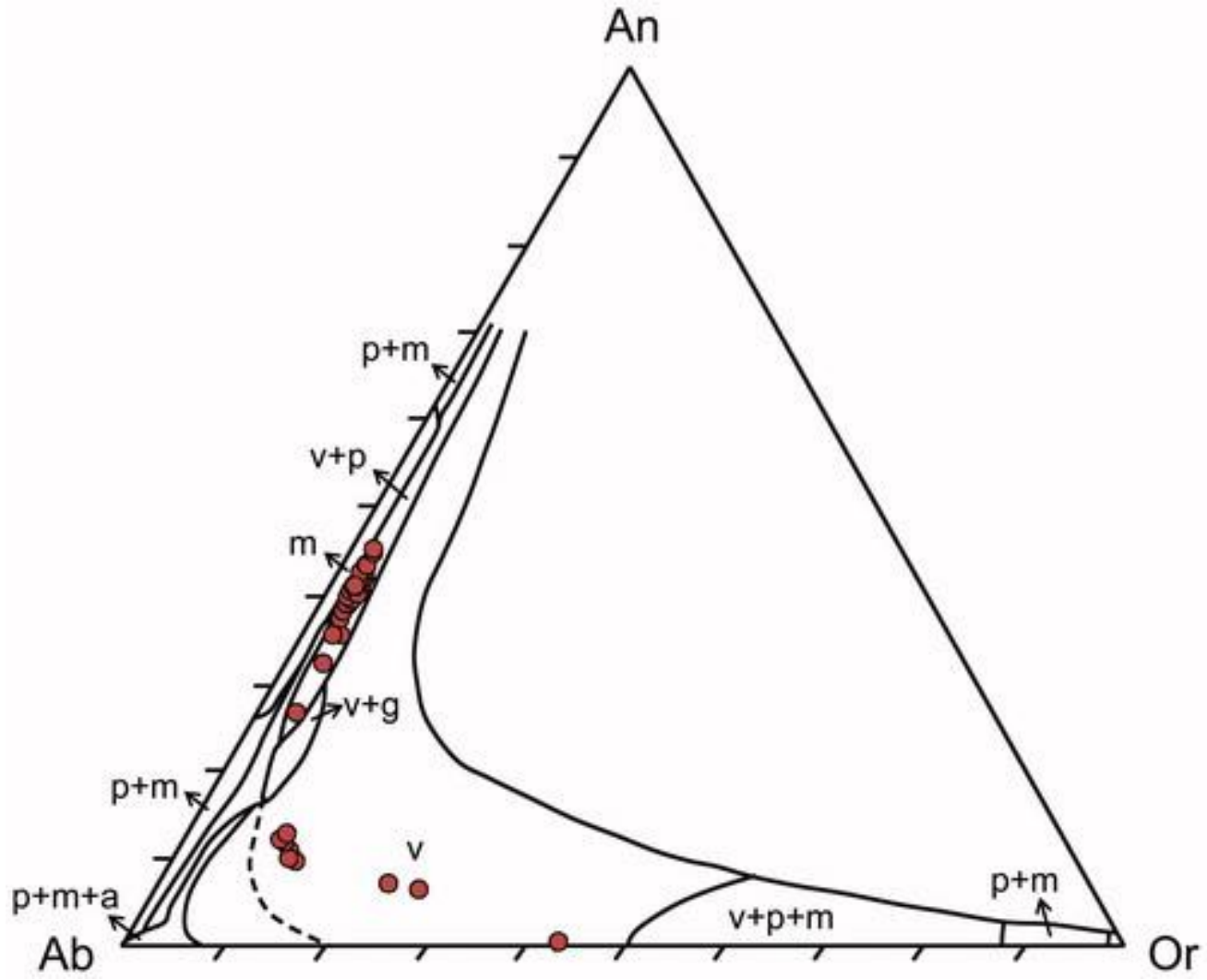


FIG. 8 Crucible \#5. a) Detail of the inner surface under the digital microscope, showing two small metal prills embedded in the vitrified layer; b) Cross-section of the ceramic fabric under the SEM, showing abundant vitrified lumps with rounded porosity, in a refractory matrix dominated by elongated, angular porosity; c) Highmagnification detail of the matrix within one of the argillaceous lumps, showing crystallization of aluminium silicate crystals (probably mullite) as a result of exposure to high temperatures; d) Detail of the cross-section at the inner surface, showing a relatively large metal prill embedded in a vitrified layer that shows signs of postdepositional weathering.
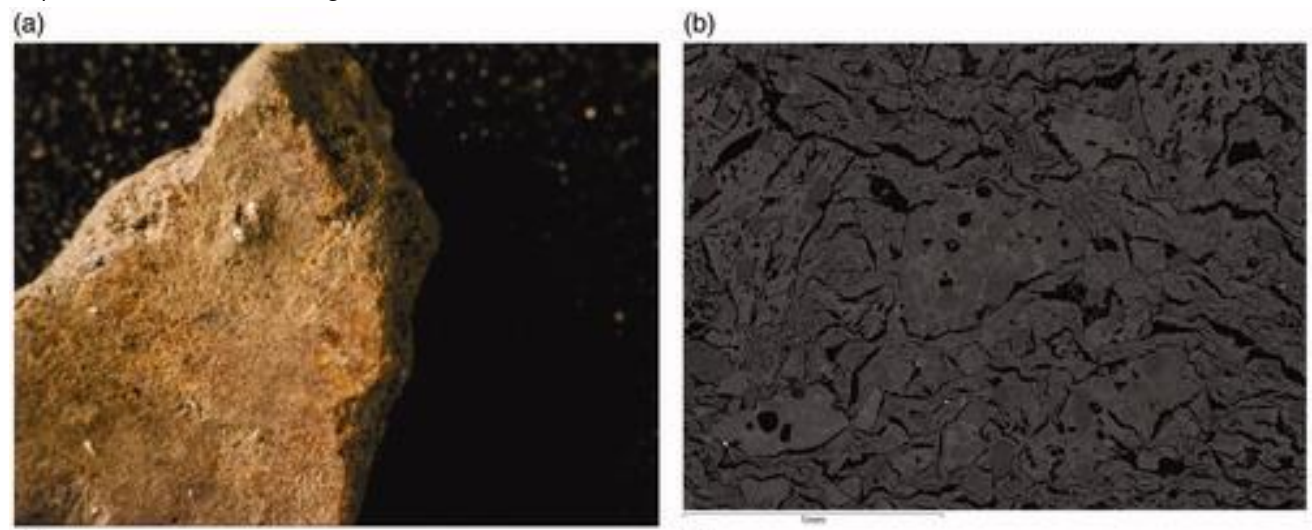

(c) (d)
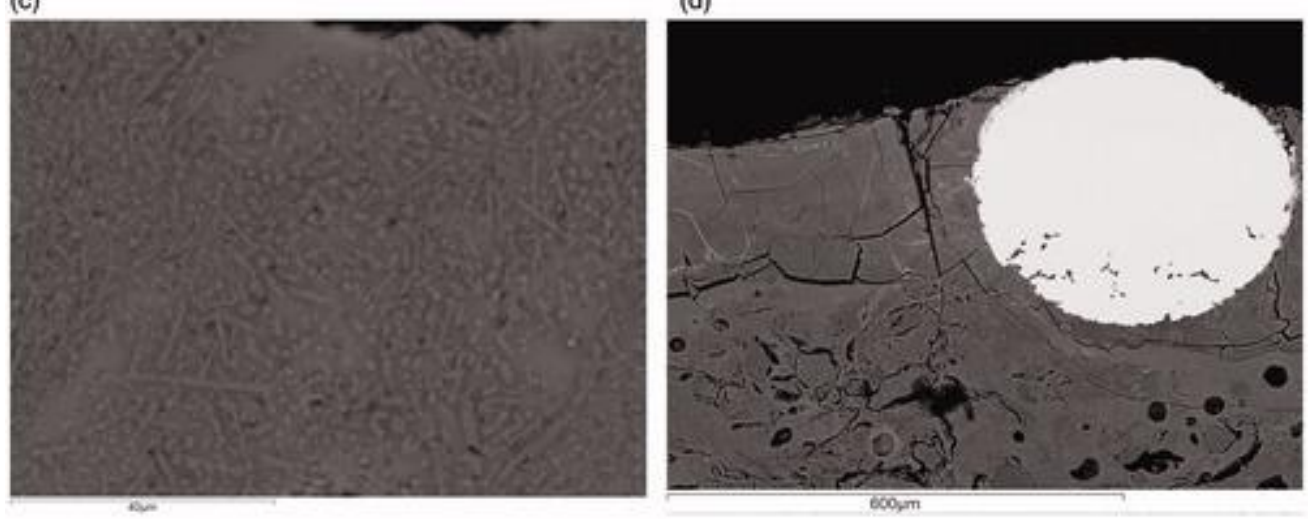

Crucible \#1 is covered by a thin vitrification surface layer, most noticeable on the interior, ranging from yellow to red and brown in colour. Within this, numerous metallic globules are noticeable, varying in diameter from less than ten to several hundred micrometres, as well as round voids (Fig. $3 \mathrm{a}-\mathrm{c}$ ). Better-preserved metal globules are dominated by silver with low levels of copper $(<4 \%)$ and iron $(<0.5 \%)$, except for one prill with as much as $10 \%$ copper and $22 \%$ iron. A more corroded globule showed a small amount of gold (Table 3). The thin vitrification layer is enriched primarily in soda and potash compared to the ceramic body, in addition to low concentrations of oxides of iron, calcium, phosphorus, copper, zinc, lead and, in some individual areas, platinum and tin (Table 2). A few residual minerals, rich in iron and copper, were identified in this layer, sometimes partly melted and re-crystallizing in acicular shapes. Clearly, this crucible was used for the melting of silver, probably alloyed with a small amount of copper. However, the slag enrichment in heavy elements makes it possible that gangue-rich native gold could have been melted here too, perhaps in a separate operation.

\section{DISCUSSION: CRUCIBLES, GOLDSMITHING PRACTICES AND ALTERNATIVE ECONOMIES}

The analyzes presented in the previous section offer new insight into the metallurgical technologies materialized in colonial Mompox, including the provision of raw materials and tools, and their utilization. This technical information is, in turn, a material reflection of the broader social and economic phenomena that shaped this goldsmithing town. The picture 
becomes richer when archaeometallurgical analyzes are compared and contrasted with relevant historical sources. In this section, the archaeological data is supplemented with historical information. On the basis of this integration we highlight the significance of the crucibles and subsequently attempt a more vivid picture of gold and goldsmithing as key elements in the reconfiguration of the social identities and economic practices of indigenous peoples, pardos, mestizos and Spaniards.

\section{IMPORTING, MAKING AND USING CRUCIBLES}

Crucibles must have been among the most important tools for silversmiths and goldsmiths, and were essential for assayers. As such, it is surprising that they are typically not listed in historical inventories of plateros (literally 'silversmiths', but often used as a generic name for those working with precious metals - see below). Both in the will of Pedro Lopez, a platero who died in 1638 in the city of Tunja in New Granada, ${ }^{34}$ and in a list of tools made up from the wills, sales contracts and notarial and criminal cases of twelve indigenous plateros who worked in Peru, Ecuador and Bolivia during the 17th century, ${ }^{35}$ crucibles are almost absent. Only Francisco Bello, who did not have a crucible as such but the material to make it, and Nicolas de Salas, refer to crucibles. ${ }^{36}$ The same can be seen among the plateros of Cuenca in Ecuador. ${ }^{37}$ This absence might be linked with the disposable nature of a crucible and its limited lifetime, and it may also suggest that some of the silversmiths worked and joined sheets and wires, rather than melting and casting alloys - but this is unlikely to be the full explanation. Besides the examples reported in this paper, the only other crucibles from colonial contexts in Colombia that we know of are those from Santa María la Antigua del Darién. $^{38}$

As stated above, there is archaeological information to show that Europeans took crucibles to the American colonies, which is not surprising since the exploitation of mineral wealth was one of the major drivers behind the colonial enterprises. This movement of European crucibles to America is not restricted to the early colonial period; for example, the numerous 18th-century crucibles recovered in the mint of Rio de Janeiro ${ }^{39}$ can be identified as German with some confidence. ${ }^{40}$ As such it is plausible, and indeed probable, that European crucibles would be found in Mompox and other Colombian sites where there was work with metalsbe it the assaying and melting of loot and fresh gold, or other artisanal practices. The four quartz-tempered crucibles presented in this paper might well constitute evidence for this, although this cannot be confirmed without further work. In a preliminary search on archival documents in Colombia, ${ }^{41}$ no reference was found to crucibles of European origin arriving at the shores of New Granada; nonetheless, this is a search that needs to be explored in further detail.

At the same time, goldsmiths would have sought materials to make their own crucibles, as corroborated by the local crucible found in Santa Cruz. This is, as far as we are aware, the first colonial crucible conclusively identified as having been made in America, although it is unlikely to be exceptional. In the inventory of Francisco Bello, a 17th-century Peruvian platero, there is a record of 'two earthenware jars full of clay for making crucibles'. ${ }^{42}$ More detailed references come from later periods. Alexander Von Humboldt (1769-1859), a German scientist who travelled extensively in Colombian territory during the early 19th century, provided a thorough description of clays and crucibles when travelling the Momposina Depression: 
South of Mompox, hard calcareous fetid grayish-black, without petrifications, at Morrocoyo; but everything seems to announce the proximity of the primary mountain. The city is paved with granite, gneiss and micaceous schist, full of iron persulfide containing gold ... Near Mompox, especially in El Banco, excellent Letten and Bol. I saw a clay crucible, poorly kneaded, sundried, in which they smelted gold and silver six or seven times. Don Ramón del Corral owns a pottery in the city's south end. Work there is slow, of poor quality, and moreover carried out by slaves! It is usual that the vessels they use to cool water at night are varnished over. Little evaporation. A round, cylindrical oven, 8 to 9 foot high to put stuff in the fire without a grill; the flame gets into the oven through vaults. ${ }^{43}$

A ceramic-making tradition survives in Mompox and the memories of the oldest ceramists in town refer to deep roots in colonial times. The town's colonial houses display numerous roof tiles that are likely to be local products, possibly made at the first kiln built and managed by the Jesuits who arrived in Mompox in 1643 (maestro ceramist José Canedo, interviewed by Lobo Guerrero in 2013). Goldsmiths' memories are also a good source of information.

Noteworthy is the popular knowledge still held among the eldest goldsmiths, concerning the use of shells and charred marine-snails mixed with mud; some of them reported that the mix should have some agua de panela, sugar cane dissolved in water, to give greater consistency to the moulds used in the casting technique. ${ }^{44}$ It is worth noting that shell temper would not have constituted ideal tempering material for crucibles, as this would decompose under the high temperatures required by metallurgical reactions affecting the vessels' performance. Crucible \#4 shows no evidence of such tempering practice. Likewise, Humboldt's reference to a sundried crucible is interesting in that it potentially reveals a practice that differs from the European tradition, where crucibles were pre-fired to high temperatures before use. Without evidence for unused crucibles, however, this point cannot be corroborated archaeologically.

More generally, the manufacture of metallurgical crucibles in colonial Mompox raises interesting questions as to the possible adaptation of European knowledge to the American environments and traditions, or possible technological syncretism. Potentially, goldsmiths could have continued to make crucibles following indigenous traditions, but they could also have learned new designs by examining and attempting to reverse-engineer extant examples, by observing European potters and/or perhaps by reading some of the metallurgical treatises or books of secrets that proliferated since the 16th century. The latter option does not appear likely based on book inventories of colonial plateros in the Andes to date, ${ }^{45}$ where there is no entry at all for manuals or reference books on goldsmithing. The will of platero Pedro Lopez includes a book list that is rich in volumes concerning the teaching of the Christian doctrine, but none linked in any way to goldsmithing. ${ }^{46}$

Unfortunately, we know very little about pre-Columbian technical ceramics and only a small handful of the few extant examples have been analyzed. Notwithstanding some variability, early crucibles and moulds generally appear very fine-grained and carbon-rich, hence significantly different from crucible \#4. ${ }^{47}$ Equally, lacking technical data on domestic or industrial ceramics made in Mompox, we cannot explore the extent to which ordinary ceramic fabrics would have been modified to optimize performance in the metallurgical furnace. These questions therefore must remain in the agenda for future research.

\section{GOLDSMITHING TRADITIONS, ALTERNATIVE ECONOMIES AND SOCIAL PHENOMENA}

The analysis of the residues within the Mompox crucibles is informative of goldsmithing practices in this colonial town, but also of broader social processes such as continuities with 
pre-Columbian traditions, the introduction of new metallurgical repertoires, contraband and resistance to authority and relationships between indigenous peoples and colonists. These are all essential cultural practices for the economic life of the colonies, as studied in Spanish settlements in the Americas and the Caribbean. ${ }^{48}$

The conclusive identification of unrefined gold dust being melted in crucible \#2 is best contextualized with reference to other events recorded historically. In 1690, Jose Sosa, pardo (descendants of West Africans, Native Americans and Europeans), freeman, carpenter and grocer, hid a small petaquilla, or wooden box, in the house of Dominga de Sosa, his aunt, morena (black) and a freewoman. When Spanish inspectors went to Dominga's dwelling in the outskirts of Mompox, they found the petaquilla containing the following items: a bag with 131 pesos and a real (units of currency), 22 pesos and five reales, gold powder from pesquerías (gold obtained in river washeries), a silver cubilete (beaker) and three spoons, another piece of gold paper from Loba without the quinto real, a pearl bead necklace of five wires and ten gold beads, a necklace with seventeen gold beads, a pair of earrings and different bits of gold, five gold doubloons and a piece of taffeta.

When inspectors asked Jose how he had obtained these goods, he replied that they had all come from a contraband cargo. They noted that no object had been quintado and asked when, how and from whom he had obtained the gold. To these questions Jose replied that the gold powder came from the bogas (indigenous people and black Africans sailing the Magdalena River in canoes carrying goods) and the rest of the items from people who sold them at a retail value. The inspectors confiscated all the goods to later auction them. During his defence he also attested that he was in charge of keeping safe some goods that belonged to the Spaniard Francisco Alvarez. These items were also the product of illicit trade. ${ }^{49}$

From this document some insights can be gained. First, it is clear that contraband involved indigenous peoples, pardos and mestizos, but also Spaniards. All alike bought and sold gold that came directly from the river to engage in all kinds of trade. This type of gold was not quintado, which was extremely detrimental to the Spanish Crown. Secondly, many of the commercial, formal and informal businesses were not regulated, and therefore the circulation of gold, powdered or in the form of objects, became part of the day-to-day commercial life. The legal and the illegal coexisted and engaged both colonized and colonizers in power games where gold was an essential component of a contested landscape. ${ }^{50}$

While it would be impossible to tell if goldsmiths routinely worked with gold that was not quintado, it is conceivable that they tended to obtain gold directly from indigenous and black Africans miners working on alluvial mining. Crucible \#2, and perhaps crucible \#1, too, support this statement. In spite of the Spaniards' attempts to assay, control and tax all the gold in circulation and the likely availability of scrap metal, goldsmiths continued to source alluvial gold (polvo de oro, gold dust). It is very likely this type of gold dodged any form of control by the authorities and was therefore the basis of contraband and illicit traffic. ${ }^{51}$

Of course, the melting of alluvial gold dust is an activity with long roots in the preColumbian past, which survives into the colonial period, but now with very different social and political implications. The same applies to the use of tumbaga alloys. In the inventory of assets of Don Gonzalo Jose de Hoyos, Marquis of Torrehoyos, signed in Cartagena de Indias on 8 April 1805, there was 'a chain of gold filigree ... a reliquary with a string of gold filigree ... a couple of bracelets a la tumbaga, with gold snakes ... ${ }^{52}$ It is not possible to tell whether the bracelets owned by the Marquis were old, pre-Columbian metalwork preserved 
for centuries or, indeed, items of new manufacture made by colonial goldsmiths. The evidence from Mompox adds important information to this picture in providing material evidence of the melting and manufacture of tumbaga artefacts in the colonial period. At Trespalacios House, not only a crucible with tumbaga residues was recovered (\#5), but also a corroded, cross-shaped metal object that $\mathrm{pXRF}$ analyzes confirmed as containing gold, copper and silver. The silver-rich tumbaga within crucible \#3 from San Francisco might just reflect a mixture of alloys from different uses, but it might also point to the deliberate manufacture of tumbaga-like, ternary alloys in colonial Mompox. Whatever the case, it is striking that the word tumbaga is still being used as different from gold into the early years of the 19th century.

Finally, the melting of silver-copper alloys, as attested to in crucibles \#1 and \#4, is testament to deliberate silversmithing practices that only started after colonial contact. Given that silver metallurgy was unknown in northern Colombia prior to European arrival, we can hypothesize that the expanded transport networks developed by European interests might have allowed the arrival of silver from elsewhere in South America, paving the ground for the creation of artefacts with materialities not previously known around Mompox. It is also possible that the silver melted in the Mompox crucibles arrived in the form of coins, which would come readily alloyed with a small amount of copper, as documented here. If so, the crucibles would illustrate another form of illegal activity that is likely to have been widespread. Furthermore, it is important to note that in San Francisco and, perhaps, in Santa Barbara, we have evidence of silver and gold alloys being melted at the same site, which suggests that silver- and goldsmithing may well have been part of the repertoires of individual artisans. In this sense, the term platero (silversmith) used in Spanish documents is likely to be a generic name. This is certainly the case in a colonial document referring to Muisca artisans, where a differentiation is made between plateros (who made jewellery) and santeros (who made 'saints' or figurines). ${ }^{53}$ The lack of chronological certainty makes it difficult to date precisely the introduction of silversmithing in Mompox. While an early colonial date may be hypothesized, it should be noted that the predominance of silver over gold alloys that we witness today is a relatively recent phenomenon developing over the last two centuries, and partly due to the 19th-century change in the river course that has left Mompox more isolated from communications and gold sources.

\section{CONCLUSION}

The study of early colonial archaeometallurgical remains in Colombia is still in its infancy. This may be partly due to the relative scarcity of these types of materials, even though it is likely that there are many more extant examples than those apparent from published literature. Another reason may be that finished artefacts inevitably have more aesthetic appeal than the humble tools and by-products of their manufacture. Crucibles and slag, however, are rich in information about relationships among people, and between these and their changing environments. In this paper we have revealed not only possible evidence for the use of European crucibles in Colombia, but also proof of the manufacture of these vessels locally in Mompox. These crucibles were used for the melting of alluvial gold, probably behind the Crown's back, but also of traditional tumbagas and new silver alloys. With support in historical documents, we argued that these are all likely to have been more widespread practices than hitherto recognized, engaging indigenous peoples, pardos, mestizos and Spaniards. These crucibles are thus the materialization of the various - and sometimes conflicting - streams of materials, people and interests that converged in Mompox. 
Thanks to its strategic location, the village of Mompox was an enclave, a truly advantageous gathering place for trade, storage and contraband in gold and goods. These commercial dynamics laid the foundation for the Crown to designate Mompox as a village where gold should be quintado, allowing therefore a good amount of circulating gold. Yet, Mompox was not only a transit point for commerce in gold. ${ }^{54}$ In Mompox gold entered, remained, was exchanged and, more importantly, was lost. Gold, silver and copper were melted, mixed and shaped by a variety of people. These were all key elements of the daily life of the village and, as such, crucial components of the new identities developed during the colonial period, and of the tensions between tradition and imposition. The socioeconomic implications of this craft can only be gleaned if we first unlock these practices as preserved in the archaeological and archival record.

\section{ACKNOWLEDGEMENTS}

We are very grateful to the Colombian Institute of Anthropology and History for their permission to carry out this study, to Tom Gregory at the UCL Institute of Archaeology for technical support with SEM analyzes, and to Ian Freestone at the same institution for his advice on the mineralogy of crucible \#4.

\section{RESUMEN}

Tradiciones orfebres e innovaciones en la Colombia colonial: estudio analítico de crisoles de Santa Cruz de Mompox

La conquista española de Colombia en el siglo XVI trajo nuevas tecnologías que alteraron e interactuaron con las tradiciones metalúrgicas nativas. En el pueblo colonial de Santa Cruz de Mompox, reconocido por su tradición orfebre, se mezclaron grupos indígenas y españoles con efectos trancendentales para sus tecnologías y conocimiento metalúrgico. Sin embargo, se sabe poco sobre la metalurgia colonial, sus continuidades y cambios con respecto al período precolombino. Presentamos aquí la caracterización analítica de cinco crisoles recuperados en Mompox y la evidencia documental relevante. Encontramos evidencia de la fabricación local de crisoles, así como de la fusión de polvo de oro sin refinar, tumbaga (aleaciones de oro, cobre y plata) y plata. Estas prácticas metalúrgicas ilustran actividades probablemente ilegales, la continuidad con las tradiciones precolombinas en el uso de tumbagas y la introducción española de la plata en el norte de Colombia. Proponemos que los restos metalúrgicos nos pueden informar de negociaciones sociales y económicas más amplias que incluyeron a pueblos indígenas, a mestizos y a españoles, y que son fundamentales para comprender la configuración de la realidad colonial.

Notes

1 Arquez and Peñas 1994, 11-12; Fals Borda 1979; Herrera 2002, 72-3; Le Roy Gordon $1983,17$.

2 Falchetti 1995; Plazas et al. 1993; Plazas \& Falchetti 1981.

3 Falchetti 1995, 298.

4 Arquez \& Peñas 1994; Di Filippo 2010; Jaramillo 1991, 52, 57.

5 Herrera 2002.

6 Fals Borda 1979, 35B; Salzedo del Villar 1987, 51.

7 Peñas Galindo 1986, 49; Sánchez Reyes 2008, 488; Vetter Parodi 2008, 155.

8 Arquez \& Peñas 1994; Daza 2009; Pérez 2012; Salzedo del Villar 1987. 
9 Corradine 1981; Pérez 2012, 17.

10 Cotter 1992; Martinón-Torres \& Rehren 2007; 2009; Monette 2013.

11 Meanwell et al. 2013; Plaza \& Martinón-Torres 2015; Zori \& Tropper 2013.

12 Llanos 2015; Sáenz Obregón et al. 2007.

13 Pérez 2012.

14 Therrien et al. 2002.

15 Lobo Guerrero Arenas 2016.

16 Cotter 1992; Martinón-Torres \& Rehren 2009.

17 Freestone 1989; Martinón-Torres \& Rehren 2009.

18 Martinón-Torres et al. 2006; 2008.

19 Amores Carredano \& Lloret Marín 1995.

20 Martinón-Torres \& Rehren 2009.

21 Freestone 1982.

22 Trevena \& Nash 1981.

23 Concha \& Macía 1993; De Bonis et al. 2016; Le Bas et al. 1986.

24 Droux and Delaloye 1996; Galvis \& De la Espriella 1992; Royero Gutierrez \& Clavijo Torres 2000; Vaňkova et al. 1993.

25 cf. Dungworth 2000; Rademakers \& Rehren 2016.

26 Martinón-Torres \& Rehren 2014.

27 e.g. Rademakers \& Rehren 2016.

28 Martinón-Torres \& Uribe-Villegas 2015; Uribe-Villegas \& Martinón-Torres 2012.

29 Galvis \& De la Espriella 1992; Royero Gutierrez \& Clavijo Torres 2000.

30 West 1972, 15.

31 Royero Gutiérrez \& Clavijo Torres, 2000, 69-72.

32 e.g. Meeks \& Tite 1980; Ogden 1977.

33 Patterson 1971.

34 Fajardo de Rueda 1993, 3.

35 Vetter Parodi 2013, 206.

36 Vetter Parodi 2013, 204.

37 Paniagua \& Truhan 2003, 403.

38 Alzate Gallego 2006, 66.

39 Lima \& Da Silva 2003.

40 Martinón-Torres 2010; Martinón-Torres \& Rehren 2009.

41 Lobo Guerrero Arenas 2016.

42 Vetter Parodi 2013, 220.

43 Humboldt [n.d.].

44 Peñas Galindo 1986, 54; Rojas de Leunda 1996, 49.

45 Vetter Parodi 2013.

46 Fajardo de Rueda 1993, 3.

47 Sáenz Obregón et al. 2007.

48 Deagan 2007, 99; Roberts Thompson 2012; Schmidt and Mrozowski 1993.

49 General Archive of the Indies (AGI), Escribanía. 580A, ff. 1-140. Translation by Lobo Guerrero.

50 Lobo Guerrero Arenas 2016, 171.

51 Lobo Guerrero Arenas 2016.

52 Historical Archive of Mompox (AHM), Caja 1, 1805, n.p. Translation by Lobo Guerrero Arenas.

53 Langebaek 1987.

54 Fals Borda 1979, 35B.. 


\section{BIBLIOGRAPHY}

Alzate Gallego, A. 2006, Santa María de la Antigua del Darién: Cerámica española con texto y de contexto en el Darién colombiano, Barcelona: Grup d'Estudis Precolombins.

Amores Carredano, F. \& Lloret Marín, T. 1995, 'Un grupo de crisoles triangulares modernos en Sanlúcar de Barrameda', Società Polisportiva Ars et Labor 4, 265-72.

Arquez, O. \& Peñas, D.E. 1994, Espacio, poblamiento y sociedad en la región de Mompox, Medellín: Editorial Lealon.

Beaudry, M.C. (ed) 1993, Documentary Archaeology in the New World, New York:

Academic/Plenum.

Bevan, A. \& Wengrow, D. (eds) 2010, Cultures of Commodity Branding, Walnut Creek, CA: Left Coast Press.

Concha, A.E. \& Macía, C. 1993, 'Caracterización y clasificación geoquímica de las rocas volcánicas de Providencia en el Caribe colombiano', Geología Colombiana 18, 137-42.

Corradine, A. 1981, Mompox. Estudio morfológico y reglamentario, Bogotá: Corporación Nacional de Turismo.

Cotter, J.P. 1992, 'The mystery of the Hessian wares: post-medieval triangular crucibles', in Gaimster \& Redknap 1992, 256-72.

Daza, V. 2009, Los marqueses de Santa Coa: una historia económica del Caribe colombiano 17501810, Bogotá: Colección Cuadernos Coloniales, Instituto Colombiano de Antropología e Historia.

Deagan, K. 2007, 'Eliciting contraband through archaeology: illicit trade in 18th-century St. Augustine', Historical Archaeology. 41:4, 98-116.

De Bonis, A., Febbraro, S., Germinario, C., Giampaola, D., Grifa, C., Guarino, V., Langella, A. \& Morra, V. 2016, 'Distinctive volcanic material for the production of Campana A ware: the workshop area of Neapolis at the Duomo Metro Station in Naples, Italy', Geoarchaeology 31, 437-66.

Di Fillipo, G. 2010, La independencia absoluta Santa Cruz de Mompox. Algo del pasado, para el presente y por el futuro, Mompós: Gdife-Editores.

Droux, A. \& Delaloye, M. 1996, 'Petrography and geochemistry of Plio-Quaternary calc-alkaline volcanoes of southern Colombia', Journal of South American Earth Sciences 9, 27-41.

Dungworth, D. 2000, 'A note on the analysis of crucibles and moulds', Historical Metallurgy 34:2, 836.

Fajardo de Rueda, M. 1993, 'El taller de Pedro López platero portugués en el siglo XVII', Revista Lámpara 121:XXXI, 3-10.

Falchetti, A.M. 1995, El oro del Gran Zenú. Metalurgia prehispánica en las llanuras del Caribe colombiano, Bogotá: Banco de la República.

Fals Borda, O. 1979, Historia doble de la costa. Tomo I. Mompox y Lob, Bogotá: Carlos Valencia Editores.

Freestone, I.C. 1982, 'Application and potential of electron probe micro-analysis in technological and provenance investigations of ancient ceramics', Archaeometry 24:2, 99-116. 
Freestone, I.C. 1989, 'Refractory materials and their procurement', in Hauptmann, Pernicka \& Wagner 1989, 155-62.

Gaimster, D. \& Redknap, M. (eds) 1992, Everyday and Exotic Pottery from Europe c. 650-1900, Studies in Honour of John G. Hurst, Oxford: Oxbow.

Galvis, J. \& De la Espriella, R. 1992, 'Vulcanismo Terciario al Sur de la Isla de Mompox (Parte Nororiental de la Serranía de San Lucas)', Revista de la Academia Colombiana de Ciencias Exactas, Físicas y Naturales XVIII:70, 359-67.

Hauptmann, A., Pernicka, E. \& Wagner, G.A. (eds) 1989, Old World Archaeometallurgy. Proceedings of the International Symposium, Heidelberg 1987, Der Anschnitt Beiheft 7, Bochum: Deutsches Bergbau-Museum.

Herrera, M. 2002, Ordenar para controlar. Ordenamiento espacial y control político en las llanuras del Caribe y en los Andes centrales Neogranadinos, Siglo XVIII, Bogotá: Instituto Colombiano de Antropología e Historia y Academia Colombiana de Historia.

Humboldt, Alexander Von [n.d.], Viaje a Mompox, <http://www.banrepcultural.org/blaavirtual/exhibiciones/humboldt/mompox1.htm > [accessed 15 July 2014].

Jaramillo, E. 1991, 'Fundación de la Villa de Santa Cruz de Mompox', Boletín Historial 21-2, 43-57.

Langebaek, C.H. 1987, 'Persistencia de prácticas de orfebrería muisca en el siglo XVI: el caso de Lenguazaque', Universitas Humanística 16:27, 45-52.

Le Bas, M.J., Le Maitre, R.W., Strecketsen, A. \& Zanettin, B. 1986, 'A chemical classification of volcanic rocks based on the total alkali-silica diagram', Journal of Petrology 27, 745-50.

Le Roy Gordon, B. 1983, Sinú: geografía y ecología humana, Bogotá: Carlos Valencia Editores.

Lima, T.A. \& da Silva, M.N. 2003, 'Alquimia, ocultismo, maçonaria: o ouro e o simbolismo hermético dos cadinhos (séculos XVIII e XIX)', Anais do Museu Paulista 8/9:2000-1, 9-54.

Llanos, J.M. 2015, 'Primer taller de orfebrería prehispánica excavado en Colombia (siglos IX-XVI d.C.)', Revista Colombiana de Antropología 51:2, 293-315.

Lleras Pérez, R. (ed.) 2007, Metalurgia en la América Antigua: Teoría, arqueología, simbología y tecnología de los metales prehispánicos, Bogotá: Fundación de Investigaciones Arqueológicas del Banco de la República - Instituto Francés de Estudios Andinos.

Lobo Guerrero Arenas, J. 2016, 'The Goldsmith's Workshop: A Study of Metallurgy during the 16th and 17th centuries in Colombia', University of Bristol PhD thesis.

Martinón-Torres, M. 2010, 'Of marks, prints, pots and becherovka: freemasons' branding in early modern Europe?', in Bevan \& Wengrow 2010, 213-33.

Martinón-Torres, M. \& Rehren, T. 2007, 'Trials and errors in search of mineral wealth: metallurgical experiments in early colonial Jamestown', Rittenhouse: Journal of the American Scientific Instrument Enterprise 21, 82-97. 
Martinón-Torres, M. \& Rehren, T. 2009, 'Post-medieval crucible production and distribution: a study of materials and materiality', Archaeometry 51, 49-74.

Martinón-Torres, M. \& Rehren, T. 2014, 'Technical ceramics', in Roberts \& Thornton 2014, 107-31.

Martinón-Torres, M. \& Uribe-Villegas, M.A. 2015, 'The prehistoric individual, connoisseurship and archaeological science: the Muisca goldwork of Colombia', Journal of Archaeological Science. 63, 136-55.

Martinón-Torres, M., Rehren, T. \& Freestone, I.C. 2006, 'Mullite and the mystery of Hessian wares', Nature 444, 437-8.

Martinón-Torres, M., Freestone, I.C., Hunt, A. \& Rehren, T. 2008, 'Mass-produced mullite crucibles in medieval Europe: manufacture and material properties', Journal of the American Ceramic Society 91:6, 2071-4.

Meanwell, J.L., Paris, E.H., Cruz Alvarado, W. \& Peraza Lope, C. 2013, 'Metallurgical ceramics from Mayapan, Yucatan, Mexico', Journal of Archaeological Science 40:12, 4306-18.

Meeks, N.D. \& Tite, M.S. 1980, 'The analysis of platinum-group element inclusions in gold antiquities', Journal of Archaeological Science 7:3, 267-75.

Monette, Y. 2013, 'Ore testing at the first permanent French settlement in America, 1541-1543. Searching for the origins of fire assay crucibles used at Charlesbourg-Royal (Quebec, Canada)', Applied Clay Science. 82, 91-100.

Ogden, J. 1977, 'Platinum group metal inclusions in Egyptian goldwork', Historical Metallurgy 11:2, 53-72.

Paniagua Pérez, J. \& Truhan, D.L. 2003, Oficios actividad paragremial en la Real Audiencia de Quito (1557-1730). El corregimiento de Cuenca, León: Universidad de León.

Paniagua Pérez, J. \& Salazar Simarro, N. (eds) 2008, La plata en Iberoamérica. Siglos XVI and XIX, León: Universidad de León.

Patterson, C.C. 1971, 'Native copper, silver and gold accessible to early metallurgists', American Antiquity. 36:3, 286-321.

Peñas Galindo, D.E. 1986, 'La orfebrería momposina: el aprendizaje de la paciencia', Boletín Cultural y Bibliográfico 23:7, 45-61.

Pérez, J.F. 2012, 'Evidencias comerciales en Santa Cruz de Mompox (1540-1823). Dimensionando sus capacidades portuarias y su rol en la economía en el Nuevo Reino de Granada', Universidad de Los Andes MA thesis.

Plaza, M.T. \& Martinón-Torres, M. 2015, 'Metallurgical traditions under Inka rule: a technological study of metals and technical ceramics from the Aconcagua Valley, Central Chile', Journal of Archaeological Science 54, 86-98.

Plazas, C. \& Falchetti, A.M. 1981, Asentamientos Prehispánicos en el Bajo Río San Jorge, Bogotá: Fundación de Investigaciones Arqueológicas Nacionales. Banco de la República.

Plazas, C., Falchetti, A.M., Sáenz, J. \& Archila, S. 1993, La sociedad hidráulica Zenú. Estudio arqueológico de 2000 años de historia en las llanuras del Caribe Colombiano, Bogotá: Editorial Banco de la República. 
Rademakers, F. \& Rehren, T. 2016, 'Seeing the forest for the trees: assessing technological variability in ancient metallurgical crucible assemblages', Journal of Archaeological Science: Reports 7, 588-96.

Roberts, B.W. \& Thornton, C. (eds) 2014, Archaeometallurgy in Global Perspective: Methods Syntheses, New York: Springer-Verlag.

Roberts Thompson, A. 2012, 'Evaluating Spanish colonial alternative economies in the archaeological record', Historical Archaeology 46:4, 48-69.

Rojas de Leunda, P. 1996, 'Un Orfebre de Mompox: el maestro Luis Guillermo Trespalacios', Revista Hispanoamericana 19, 46-51.

Royero Gutierrez, J.M. \& Clavijo Torres, J. 2000, Mapa Geológico Generalizado del Departamento de Bolívar, Escala 1:400.000. Memoria Explicativa, Bucaramanga: Ingeominas.

Sáenz Obregón, J., Cardale de Schrimpff, M., Obando, P., Bray, W., Herrera, L., Jiménez, A., Doherty, C. \& Scott, D., 2007. 'Tras las huellas de los orfebres: herramientas para la metalurgia en las sociedades tempranas del Valle del Cauca', in Lleras Pérez 2007, 363-408.

Salzedo del Villar, P. 1987, Apuntaciones historiales de Mompox, Cartagena: Espitia Hermanos.

Sánchez Reyes, G. 2008, 'Relicarios de plata en Nueva España: refugios materiales de la santidad', in Paniagua Pérez \& Salazar Simarro 2008, 483-96.

Schmidt, P.R. \& Mrozowski, S.A. 1993, 'Documentary insights into the archaeology of smuggling', in Beaudry 1993, 32-42.

Therrien, M., Uprimny, E., Lobo Guerrero, J., Salamanca, M.F., Gaitán Ammann, F. \& Fandiño, M. 2002, Catálogo de cerámica colonial y republicana de la Nueva Granada: Producción local y materiales foráneos (Costa Caribe, Altiplano Cundiboyacense-Colombia), Bogotá: Fundación de Investigaciones Arqueológicas Nacionales. Banco de la República.

Trevena, A.S. \& Nash, W.P. 1981, 'An electron microprobe study of detrital feldspar', Journal of Sedimentary Petrology 51, 137-49.

Uribe Villegas, M.A. \& Martinon-Torres, M. 2012, 'Typology, technology, composition and context of Muisca metalwork (Colombia, AD 600-1800): a database', Journal of Open Archaeology Data 1, e4. <http://doi.org/10.5334/4f60dd6baa298> [accessed 4 March 2018].

Vaňkova, V., Vanek, J., Hanus, V., Fiala, J. \& Chalupsky, V. 1993, 'Geochemistry of calc-alkaline volcanic rocks in relation to deep structure of Ecuador and southern Colombia', Global Tectonics and Metallogeny 4:3, 113-55.

Vetter Parodi, L. 2008, Plateros indígenas en el virreinato del Perú: siglos XVI y XVII, Lima: Fondo Editorial de la Universidad Nacional Mayor de San Marcos, Compañía de Minas Buenaventura S.A.A.

Vetter Parodi, L. 2013, 'De la tecnología orfebre precolombina a la colonial', Bulletin de l'Institut Français d'Études Andines 42:0, 203-35.

West, R. 1972, La minería de aluvión en Colombia durante el período colonial, Bogotá: Universidad Nacional de Colombia. 
Zori, C. \& Tropper, P. 2013, 'Silver lining: evidence for Inka silver refining in northern Chile', Journal of Archaeological Science 40:8, 3282-92.

Author contributions

The archaeological research from which this study is derived was directed by JLGA. MMT and JLGA designed the study and drafted the manuscript. All authors acquired data and approved the final manuscript. 